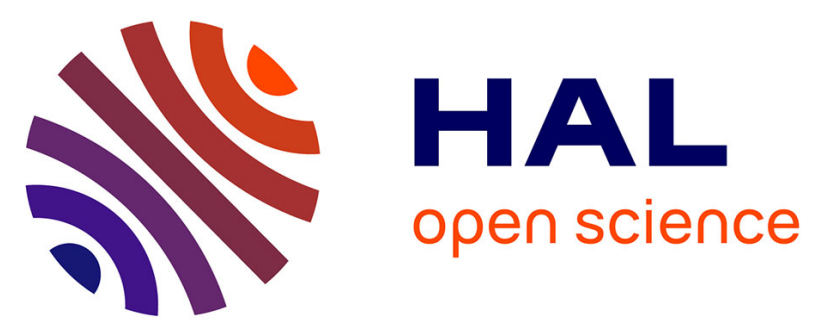

\title{
Adsorption of Alexa-Labeled Bt Toxin on Mica, Glass, and Hydrophobized Glass: Study by Normal Scanning Confocal Fluorescence
}

Jean-Marc Janot, Michel Boissière, Thierry Thami, Emmanuel Tronel-Peyroz, Nordine Helassa, Sylvie Noinville, Hervé Quiquampoix, Siobhán Staunton, Philippe Dejardin

\section{To cite this version:}

Jean-Marc Janot, Michel Boissière, Thierry Thami, Emmanuel Tronel-Peyroz, Nordine Helassa, et al.. Adsorption of Alexa-Labeled Bt Toxin on Mica, Glass, and Hydrophobized Glass: Study by Normal Scanning Confocal Fluorescence. Biomacromolecules, 2010, 11 (6), pp.1661 - 1666. 10.1021/bm100313n . hal-01701137

\section{HAL Id: hal-01701137 \\ https://hal.umontpellier.fr/hal-01701137}

Submitted on 27 Jan 2021

HAL is a multi-disciplinary open access archive for the deposit and dissemination of scientific research documents, whether they are published or not. The documents may come from teaching and research institutions in France or abroad, or from public or private research centers.
L'archive ouverte pluridisciplinaire $\mathbf{H A L}$, est destinée au dépôt et à la diffusion de documents scientifiques de niveau recherche, publiés ou non, émanant des établissements d'enseignement et de recherche français ou étrangers, des laboratoires publics ou privés. 


\section{Adsorption of Alexa-labeled $B t$ toxin on Mica,}

\section{Glass and hydrophobized glass: Study by Normal}

\section{Scanning Confocal Fluorescence}

Jean-Marc Janot ${ }^{1}$, Michel Boissière ${ }^{1 a}$, Thierry Thami ${ }^{1}$, Emmanuel Tronel-Peyroz ${ }^{1}$, Nordine Helassa $^{2 b}$, Sylvie Noinville ${ }^{3}$, Hervé Quiquampoix ${ }^{2}$, Siobhán Staunton ${ }^{2}$ and Philippe Déjardin $^{*}$

${ }^{1}$ Institut Européen des Membranes, Université Montpellier 2, UMR5635 (ENSCM, CNRS, UM2), CC047, 34095 Montpellier Cedex 5, France

2 UMR 1222, Ecologie Fonctionnelle et Biogéochimie des Sols, INRA, Montpellier, France

3 Laboratoire de Dynamique, Interactions et Réactivité, UMR 7075, CNRS, Thiais, France *corresponding author, philippe.dejardin@iemm;univ-montp2.fr

Title running head : Toxin adsorption on mica and glass

${ }^{\text {a }}$ Present address : ERRMECe, UFR Sciences et Techniques, Université de Cergy-Pontoise, 2 avenue Adolphe Chauvin - BP222, 95302 Pontoise Cedex, France

${ }^{\mathrm{b}}$ Present address : CNRS-IBS, LIM, 41 rue Jules Horowitz, 38027 Grenoble, France 


\begin{abstract}
We studied the kinetics of adsorption of alexa-labeled Bt toxin Cry1Aa, in monomer and oligomer states, on muscovite mica, acid-treated hydrophilic glass and hydrophobized glass, in the configuration of laminar flow of solution in a slit. Using normal confocal fluorescence through the liquid volume allows visualizing the concentration in solution over the time of adsorption, in addition to the signal due to the adsorbed molecules at the interface. The solution signal is used as calibration for estimation of interfacial concentration. We found low adsorption of the monomer compared to oligomers on the three types of surface. The kinetic adsorption barrier for oligomers increases in the order hydrophobized glass, muscovite mica, acid-treated hydrophilic glass. This suggests enhanced immobilization in soil if toxin is under oligomer state.
\end{abstract}

Keywords: Bt toxin; Bt adsorption; adsorption kinetics; protein adsorption; GMO 


\section{Introduction}

A large proportion of commercial crops of genetically modified plants synthesize the insecticidal protein known as $B t$ toxin originally produced by the soil bacteria Bacillus thuringiensis. The risks associated with the liberation of such toxins in the soil must be evaluated $^{1} . B t$ toxin can be introduced into soil via decomposition of plant biomass and root exudation. The use of Bt crops can give markedly improved crop yields due to efficient protection against pests, but their use raises the question of exposure of non-target organisms and the acquisition of resistance by target insects. The mineral composition of soil is very varied. Therefore, adsorption on model minerals such as goethite, kaolinite, montmorillonite, rectorite and silicon dioxide is often examined ${ }^{2-5}$. As for other proteins at interface we could expect phenomena such as irreversible adsorption, conformational changes, exchange with other solutes, and $\mathrm{pH}$-dependence ${ }^{6-9}$. Adsorption on soil may also increase the life time of the protein by physical protection against enzymatic degradation ${ }^{10,11}$ and it has been reported that insecticidal activity is conserved ${ }^{12}$. The aim of the present work is to contribute to the understanding of the fate of the toxin in the presence of hydrophilic minerals, such as muscovite mica and glass, and hydrophobic surfaces via a surface-treated glass.

The state of the protein in solution is an important parameter in determining adsorption properties. At large concentrations, high $\mathrm{pH}$ and high salt concentrations are required to inhibit polymerisation of this protein ${ }^{13,14}$. Among the methods of preparation of the toxin reported in the literature, only a few verify that the monomer state was maintained in solution. The protein dimerizes easily ${ }^{15}$ and so the monomer is difficult to maintain in solution. Although the tetramer is the entity responsible of the perforation of the insect midgut wall $^{16}$, this tetramer is formed on the bilayer from monomers in solution. We present a study of the different adsorption behaviours of monomer and oligomers of Cryl Aa. The sensitivity of the detection on the surface was obtained by labeling the toxin with a fluorescent probe. 
We used slit geometry, as in a previous work with radiolabeled proteins ${ }^{17-19}$, to create controlled laminar flow. The solution signal is used as a calibration to evaluating the interfacial concentration. In addition to the sensitivity obtained with a fluorescent label, the technique is useful in studies involving a mica surface which is not suitable for other optical techniques like total internal reflection fluorescence (TIRF), surface plasmon resonance (SPR), ellipsometry or reflectometry.

\section{Materials and Methods}

\section{Chemicals}

The CrylAa solutions were prepared in 3-(Cyclohexylamino)-1-propanesulfonic acid (CAPS, $\mathrm{pK}_{\mathrm{a}}$ 10.4) and 3-(N-Morpholino)-propanesulfonic acid (MOPS, $\mathrm{pK}_{\mathrm{a}}$ 7.2). Both buffers were purchased from Sigma (France). Decyltrichlorosilane (Aldrich, France) and reagent grade toluene (Sigma, France) were used as received. Labeling of $B t$ was performed with Alexa-fluor-594 succinimidyl ester (InvitroGen, A30008).

\section{Bt toxin and Alexa-labeled Bt}

The procedure of preparation of CrylAa toxin has been published previously ${ }^{4}$. The protein (65 $000 \mathrm{~g} / \mathrm{mol}$ ) contains 609 residues and is composed of three distinct domains. The domain I contains eight helices bearing mainly negatively charged residues while the stacked domains II and III are mainly composed of $\beta$-sheeted structures bearing positively charged residues so that the external protein surface has an uneven distribution of charges ${ }^{20,21}$. Its isoelectric point $\mathrm{pI}$ is $6.5^{22}$. Aliquots of concentrated solution were provided in CAPS $\mathrm{pH}$ 10.5. Diluted samples in $10 \mathrm{mM}$ CAPS, $350 \mathrm{mM} \mathrm{NaCl}, \mathrm{pH} 9.6$ were labelled with Alexa-594. Typically $800 \mu \mathrm{L}$ of $B t$ solution were poured on dried fluorophore Alexa-594 in molar ratio 1:1 and allowed to react for $1.5 \mathrm{~h}$ at $20^{\circ} \mathrm{C}$. The mixture was then put in an $a d$ hoc microtube with filter 
(Biospin P6) and centrifuged at $16,000 \mathrm{~g}$ for $1 \mathrm{~min}$ according to the supplier of the kit (InvitroGen). Elution of the filtrate on a preparative size exclusion chromatography column (BioRad P60; same elution buffer; $\mathrm{pH}$ 9.6) provided the pure monomer. It was verified that labelled and unlabeled samples presented the same elution curve. The final average labeling ratio [Alexa] / [protein monomer] was 0.5 - 0.7. Without centrifugation step, a substantial amount of oligomers was obtained with labeling ratio $\sim 0.1$. Labeling ratio was determined from the UV absorbances at $277 \mathrm{~nm}$ where both the label $\left(\varepsilon_{277-\text { Alexa }}=47793 \mathrm{M}^{-1} \cdot \mathrm{cm}^{-1}\right)$ and protein $\left(\varepsilon_{277-\text { protein }}=82000 \mathrm{M}^{-1} \cdot \mathrm{cm}^{-1}\right)$ absorb and at $587 \mathrm{~nm}$ where only the label $\left(\varepsilon_{587}=78000\right.$ $\left.\mathrm{M}^{-1} \cdot \mathrm{cm}^{-1}\right)$ absorbs.

After column calibration with standard proteins the apparent molar masses was 44000 $\mathrm{g} / \mathrm{mol}$ for monomer, lower than the reported value of $65000 \mathrm{~g} / \mathrm{mol}$. This may be attributed to an interaction with the column. Similar underestimation of the molar mass has been reported with another type of column in size exclusion chromatography HPLC analysis ${ }^{13}$. Oligomers were estimated to be an assembly of at least ten monomers. Tubes were stored at $+4^{\circ} \mathrm{C}$. The samples were diluted (0.1-1\% in vol) immediately before adsorption in $50 \mathrm{mM} \mathrm{NaCl}, 10 \mathrm{mM}$ CAPS buffer at the required $\mathrm{pH}$ obtained by addition of $\mathrm{HCl}$ or in $50 \mathrm{mM} \mathrm{NaCl}, 10 \mathrm{mM}$ MOPS buffer for experiments at both $\mathrm{pH} 6.3$ and 7.2.

\section{Substrates}

Hydrophilic surfaces. Muscovite mica was purchased from Metafix SA (Montdidier, France) as $5 \mathrm{~cm} \times 2 \mathrm{~cm}$ sheets. It was freshly cleaved before each experiment. Glass surfaces were microscope slides (Menzel-Glaser $25 \mathrm{~mm} \times 60 \mathrm{~mm}$ ) of thickness 140-150 $\mu \mathrm{m}$. They were made very hydrophilic with acid treatment $\left(\mathrm{H}_{2} \mathrm{SO}_{4} / \mathrm{H}_{2} \mathrm{O}_{2} 70 / 30\right.$ vol at $90^{\circ} \mathrm{C}$ for $\left.30 \mathrm{~min}\right)$ followed by extensive washing with ultrapure water. The sessile water drop contact angle was near $0^{\circ}$ with $^{23-25} \approx 5 \times 10^{14}$ silanols per $\mathrm{cm}^{2}$. The acid-treated cleaned glass will be called "hydrophilic" in what follows, to emphasize the contrast with hydrophobized glass. 
Hydrophobized glass. Glass slides after the previous treatment were dried under nitrogen flow and heated at $110^{\circ} \mathrm{C}$ in an oven for $20 \mathrm{~min}$. Then six slides, using a holder made in Teflon, were put in decyltrichlorosilane $1 \mathrm{mM}$ in toluene $(250 \mathrm{~mL})$ at $20^{\circ} \mathrm{C}$ for $1.5 \mathrm{~h}$ before rinsing with toluene (thrice) and drying under nitrogen. The water contact angle was $103.0^{\circ} \pm$ $0.9^{\circ}$ over the six slides. Eight measurements, over the entire surface, were performed on each plate with narrow distribution $\left( \pm 0.5^{\circ}\right)$, showing very homogeneous treatment on the whole surface of each item.

\section{Flow cell}

The flow cell has been described previously ${ }^{26}$. A microscope slide, just cleaned or hydrophobized, was positioned near the objective. The other wall was mica sheet with holes punched at each extremity for entry and exit of flowing solution ( Fig. 1). The channel width $w$ and height $b$ were $3 \mathrm{~mm}$ and $50-70 \mu \mathrm{m}$ respectively. The parameter characterizing the convection is the wall shear rate $\gamma$ deduced from the imposed flow rate Q according to the Poiseuille-like relation $\mathrm{Q}=(1 / 6) \gamma \mathrm{b}^{2} \mathrm{w}$. Experiments were carried out at $\mathrm{T}=19^{\circ} \mathrm{C}$ and $\gamma=$ $1000 \mathrm{~s}^{-1}$ for $30 \mathrm{~min}$ or more. Flow occurs in the $x$ direction normal to the $y$ scanning one. A typical experiment consists first to flow the buffer to get the background signal and then the protein solution. Adsorption can be measured on both walls of the slit and through the solution. Each scan lasted 30 to $40 \mathrm{~s}$. 


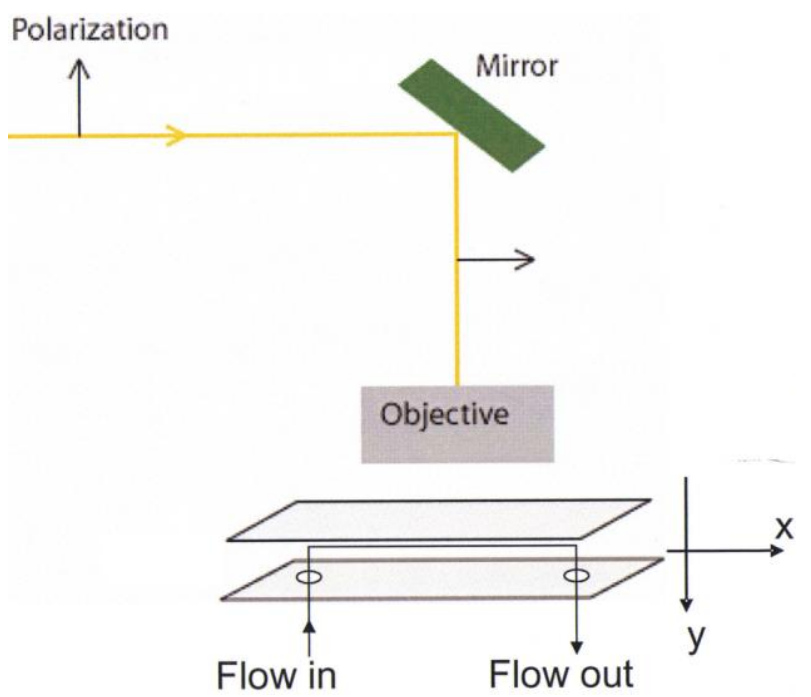

Figure 1. Schematic illustration of the directions $x$ of flow and $y$ of translation of the objective leading to the focus scanning through the thickness of the slit between the two walls of glass (top) and mica (bottom).

For technical reasons, the experimental setup was limited to about $60 \mu \mathrm{m}$ between the slit walls. With such a distance between walls, the flow was laminar as the Reynolds number was very small. Coupling between convection and diffusion leads to create a depletion layer whose thickness $\delta_{\text {depl }}$ can be estimated from the transport-limited Lévêque model ${ }^{27,28}: \delta_{\text {depl }} \approx$ $1.86(D x / \gamma)^{1 / 3}=21 \mu \mathrm{m}$ with Bt diffusion coefficient $D=7 \times 10^{-7} \mathrm{~cm}^{2} \mathrm{~s}^{-1} ; x=2 \mathrm{~cm} ; \gamma=1000 \mathrm{~s}^{-}$ ${ }^{1}$. For finite adsorption constant, such thickness remains of the same order of magnitude ${ }^{29-31}$. It can be inferred that depletion extends over about two to three times that distance. A rigorous simple analysis of initial adsorption rate would require then such a ratio for halfheight of channel over Lévêque depletion layer thickness. The present conditions with the ratio 1.5 could introduce coupling between the two faces. However we found this coupling to be small as for instance the adsorption kinetics on mica are very similar in front of strongly and mildly adsorbing wall. Axial diffusion in tubing before the cell and probably the type of slit entrance into the slit led to not ideal hydrodynamic conditions for comparison with such models. However, despite such drawback, as the conditions were very close from one experiment to another, we believe that relative variations from monomer to oligomers and 
from one surface to another, which are discussed in the present work, remain valid. Current work is in progress to improve especially the arrival of solution after buffer to approach the almost step function obtained in a radioactivity cell ${ }^{32}$ as used for adsorption studies of $\alpha$ chymotrypsin on mica $^{18}$.

\section{Optical device}

The optical device was previously described ${ }^{26}$. It is roughly similar to classical devices for confocal fluorescence studies. With respect to the previous work, an easier scanning was obtained as the step-by-step motor was changed to a piezoelectric device. A better separation of excitation and emission wavelengths was also obtained (SemRock NF01-594-25). The normal orientation of scanning with respect to the flow direction is sketched in Fig. 1. The laser energy was $500 \mathrm{nW}$ corresponding to a power density, when focusing at the interface, of the order of $180 \mathrm{~W} / \mathrm{cm}^{2}$ or less as this value does not take into account the energy loss through the objective. Despite this relatively low energy, the $x$ - position of the sample was shifted a few micrometers (typically $5 \mu \mathrm{m}$ ) between each scan to avoid any possible contribution of photobleaching, an effect sometimes observed at higher laser power without lateral shift. This is justified by measurements at $2 \mathrm{~cm}$ far from the hole of entrance. Typically 200 scans correspond then to measurements between 2 and $2.1 \mathrm{~cm}$. As for an ideal slit geometry, the transport-controlled adsorption rate varies with the (1/3) power of distance $x$ to entrance, the correction is negligible.

\section{Determination of interfacial concentration}

Scanning normal to the walls of the slit through the solution along an axis $y$ provides a data set $F(y, t)$, corresponding to the counting of photons over some time $\delta t$ at successive positions $y$, with a dependence $\delta t(y)$. The positions $y$ are not regularly spaced as large signal variations near the interface require a greater density of points than in the centre of the slit. 
One scanning process does not lead to an instantaneous profile. All the results presented correspond to linear interpolations between the data of the scans to obtain equally time-spaced instantaneous fluorescence signal profiles. Fig. 2 provides as an example such interpolated profiles $F(y, t)$ without and with adsorption at the interfaces. The interfacial concentration is estimated via calibration given by the fluorescence signal $F_{\text {sol }}$ of solution of known concentration $C_{\mathrm{b}} . F_{\text {sol }}$ is the final steady-state value of the solution signal in the cell (see Fig. $2 \mathrm{a}$ as an example). The concentration in liquid phase is then equal to the concentration of the incoming solution. The solution signal is always taken at mid-distance between the walls for, near the interfaces, the adsorption intense signal masks the true contribution of solution. $F_{\text {sol }}$ is relative to an effective volume $V$ containing solution at concentration $C_{b}$ while the signal $F_{\text {surf }}$ from surface concerns interfacial concentration $\Gamma$ over area $A$. As a first approximation, we will assume that the fluorophore is randomly oriented at interface as in solution. Then we have time $(t)$ dependent interfacial signal $F_{\text {surf }}(t) \sim \Gamma(t) A$ and calibration solution signal $F_{\text {sol }}$ $\sim C_{b} V$ with the same proportionality constant. Therefore $\Gamma(t)=(V / A)\left(F_{\text {surf }}(t) / F_{\text {sol }}\right) C_{b}$.

Based on focus radius of $300 \mathrm{~nm}$ (objective numerical aperture $1.2 ; \lambda=594 \mathrm{~nm}$ ) and volume $V \approx 1 \mu \mathrm{m}^{3}, V / A=3.5 \mu \mathrm{m}$. The convolution of the solution profile (step function at both interfaces) with the beam shape leads to a sigmoid at the interfaces with half the bulk solution signal at the interface (Fig. 2 b). We used then as surface signal $F_{\text {surf }}$ the raw signal minus half the solution signal. This correction is negligible when a strong adsorption occurs at small solution concentration. 

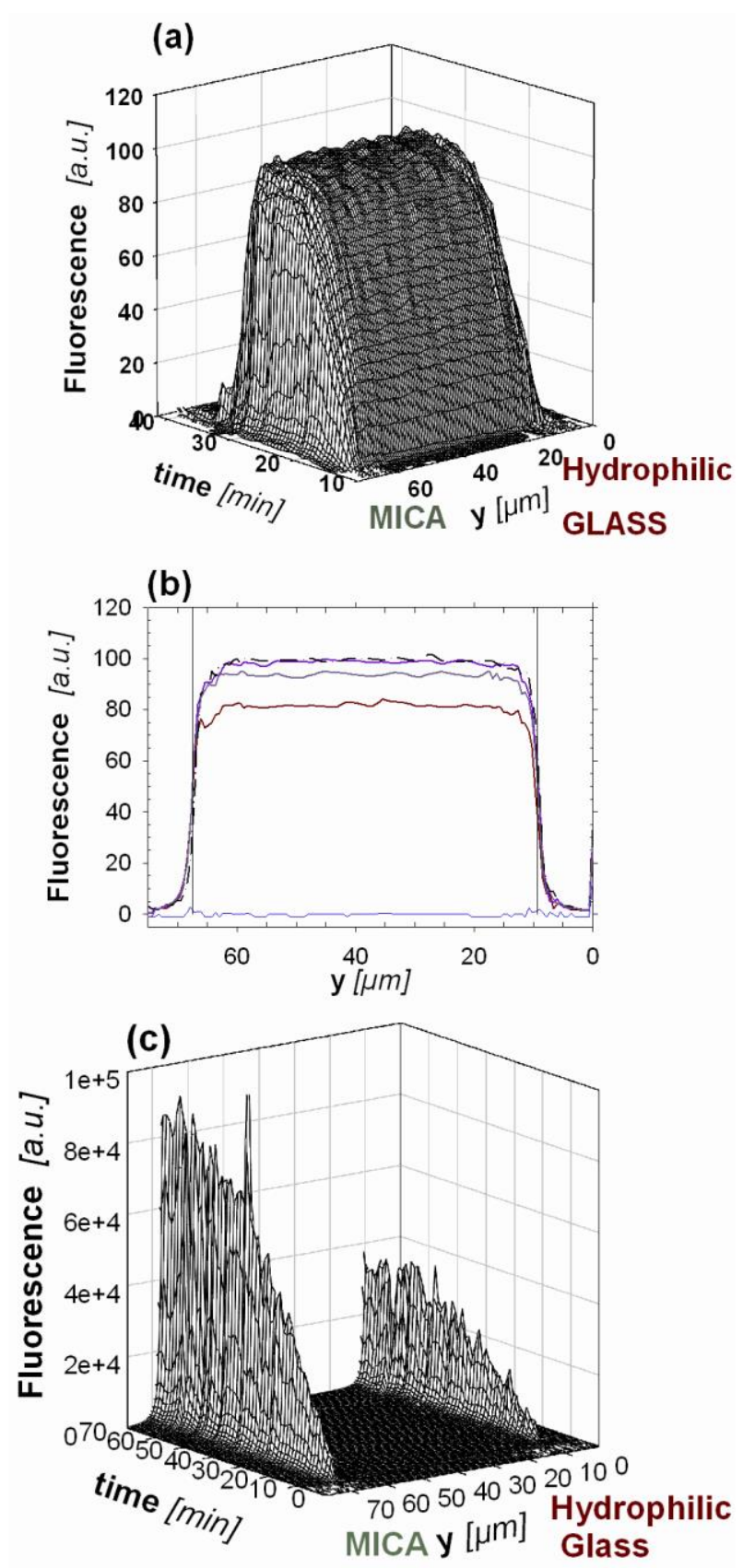

Figure 2 (a) Example of fluorescence concentration profile between two walls of hydrophilic glass $(\mathrm{y}=9 \mu \mathrm{m})$ and mica $(\mathrm{y}=67 \mu \mathrm{m})$ as a function of time when no adsorption is occurring (flowing of Alexa-labeled Bt solution at $2.0 \mu \mathrm{g} / \mathrm{mL}$ in $10 \mathrm{mM}$ CAPS pH 10.5, $350 \mathrm{mM} \mathrm{NaCl}$ ). (b) Illustration of sigmoid curve shape of solution signal at the interfaces; from bottom to top t $=10 ; 20 ; 22.7 ; 25 ; 28.3 \mathrm{~min}$. (c) Example when adsorption is occurring (flowing of oligomers solution $6.6 \mu \mathrm{g} / \mathrm{mL}$, $\mathrm{pH} 7.2)$ 
Compared to adsorption kinetics studies by means of $\gamma$-radiolabeled protein where the calibration is provided by the solution signal jump ${ }^{33}$, the use of confocal fluorescence may introduce difficulties. The $\gamma$-emission indeed is not dependent on the position of the protein, in solution or at the interface, and moreover not dependent also on its conformation and orientation. Conversely, the fluorescence properties may present such dependences. The orientation of the protein in solution is isotrope but surface may induce a preferred orientation of the adsorbed protein. Orientation changes can appear depending on surface coverage during the adsorption process ${ }^{34-36}$. Such considerations are relevant for a fluorophore firmly attached to the molecule ${ }^{26}$. In the present study the labeling was performed via a loose arm to allow fluorophore freedom of rotation with respect to protein in solution. We assumed that such freedom or random orientation existed at the interface.

\section{Results and Discussion}

Influence of $\mathrm{pH}$ on Bt adsorption $(2.0 \mu \mathrm{g} / \mathrm{mL})$ in $C A P S$

No adsorption occurred onto either interface (Fig. 2a) when $2 \mu \mathrm{g} / \mathrm{mL}$ Bt solution in $350 \mathrm{mM} \mathrm{NaCl}, 10 \mathrm{mM}$ CAPS buffer (pH 10.5) was flowing through the slit between mica and hydrophilic glass. Lower salt concentration $(50 \mathrm{mM})$ at $\mathrm{pH} 8$ and 7.3 (by addition of concentrated $\mathrm{HCl}$ ) led to the same observation. Only at $\mathrm{pH} 6.3$ a small amount was adsorbed at both interfaces. Conversely, on hydrophobized glass, we could observe a small fluorescence signal at $\mathrm{pH} 10.5$ and a much larger one at $\mathrm{pH}$ 6.3. From these series of experiments, it was inferred that significant adsorption occurred only close to the isoelectric point of the protein. Experiments at $\mathrm{pH} 6.3$ and 7.2 were then performed with MOPS instead of CAPS to maintain significant buffering power of solvent in this range of $\mathrm{pH}$. In addition, 
we focused on the difference of behavior between monomer and oligomers at interfaces. These buffers were preferred to phosphate as the dianions in this $\mathrm{pH}$ range may introduce specific effects ${ }^{9}$.

\section{Monomer Adsorption kinetics}

We studied adsorption from solutions at pH 6.3 using as buffer $50 \mathrm{mM} \mathrm{NaCl}, 10 \mathrm{mM}$ MOPS (Fig. 3). In such conditions, the Debye screening length $(1.3 \mathrm{~nm})$ is smaller than the protein size $(8 \mathrm{~nm})$. Therefore the electrostatic interactions protein / surface should be of relatively short range and involve only a part of the molecule. On mica a plateau was observed at $20 \mu \mathrm{g} / \mathrm{mL}$ after $30 \mathrm{~min}$, while a steady-state value was not attained at lower concentrations within $50 \mathrm{~min}$. The adsorption kinetics could be represented quite well by a single increasing exponential function of time, at least over the time range of this study. On the contrary, the adsorption behavior of Bt on hydrophilic glass showed an initial rapid step followed by a much slower one: the two hydrophilic surfaces can be considered as two different classes of surfaces for the toxin Bt.

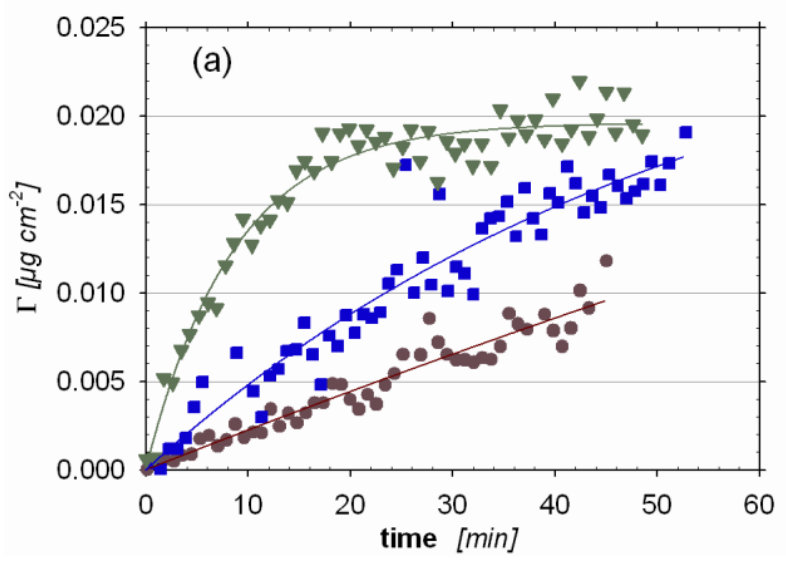




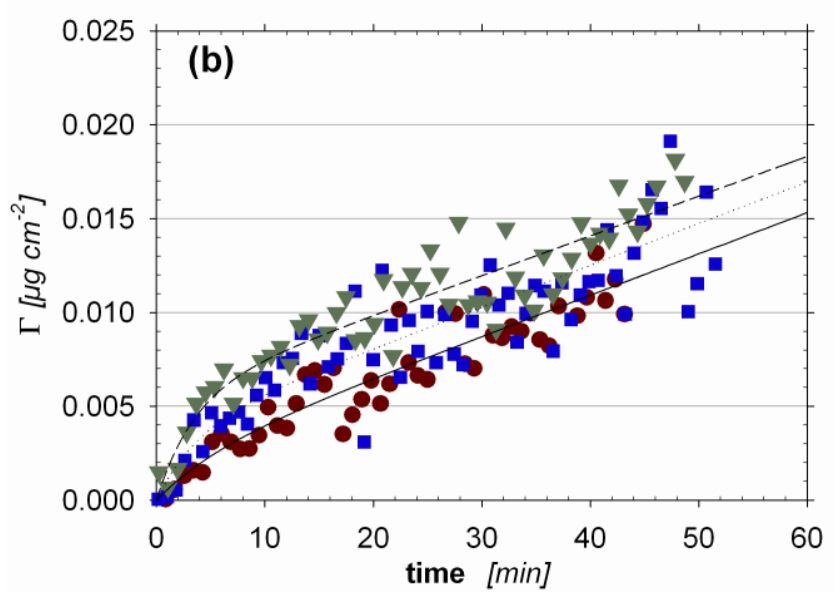

Figure 3 (a) Adsorption kinetics at pH 6.3 of monomer Bt on mica at wall shear rate $1000 \mathrm{~s}^{-1}$ in a cell of height $60 \mu \mathrm{m}$. From bottom to top: $\mathrm{C}_{\mathrm{b}}=3.3(\bullet) ; 5.3(\boldsymbol{\square}) ; 20 \mu \mathrm{g} / \mathrm{mL}(\boldsymbol{\nabla})$. (b) idem on hydrophilic glass

Over the time range of $1 \mathrm{~h}$, adsorption is almost the same on mica and hydrophilic glass, $0.015-0.020 \mu \mathrm{g} \mathrm{cm}^{-2}$ for $5.3-20 \mu \mathrm{g} / \mathrm{mL}$ solution. The same level is reached on hydrophobized glass with the lower concentration of $2.0 \mu \mathrm{g} / \mathrm{mL}$ (Fig. 4) but a higher initial kinetic constant $(3.5 \pm 0.5) \times 10^{-6} \mathrm{~cm} \mathrm{~s}^{-1}$ vs $2.4 \times 10^{-6} \mathrm{~cm} \mathrm{~s}^{-1}$ on mica. Those results suggest a slightly lower adsorption barrier of $\mathrm{Bt}$ monomer in the presence of hydrophobized surfaces compared to hydrophilic ones. Besides we observed on hydrophobic substrate the interfacial concentration as a quite sharp decreasing function of $\mathrm{pH}$ above the isoelectric point of the protein (Fig. 4)

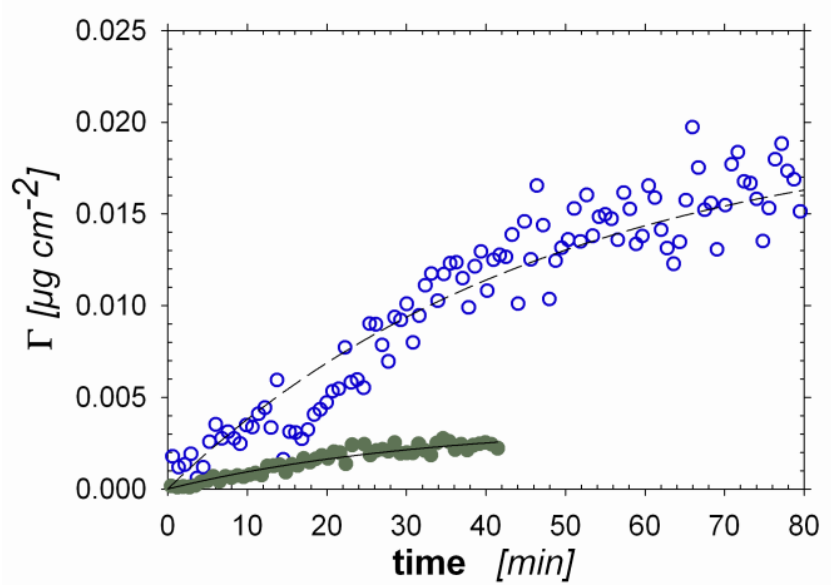

Figure 4 Adsorption kinetics from $2.0 \mu \mathrm{g} / \mathrm{mL}$ solution of monomer Bt on hydrophobized glass at pH 6.3 (open symbols) and pH 7.2 (full symbols). 


\section{Oligomers adsorption kinetics}

Two series of experiments were carried out. One at $\mathrm{pH} 6.3$ with $\mathrm{Bt}$ concentration of $13.2 \mu \mathrm{g} / \mathrm{mL}$, the other at $\mathrm{pH} 7.2$ with twice less concentration of $6.6 \mu \mathrm{g} / \mathrm{mL}$. Each series includes two experiments with mica facing either hydrophilic glass or $\mathrm{C}_{10}$-glass. Adsorption kinetics are presented in Fig. 5. We can see the small effect of the facing wall on adsorption on mica, as kinetic curves are very close to each other. This is an illustration of the small coupling between the two faces in the adsorption process.

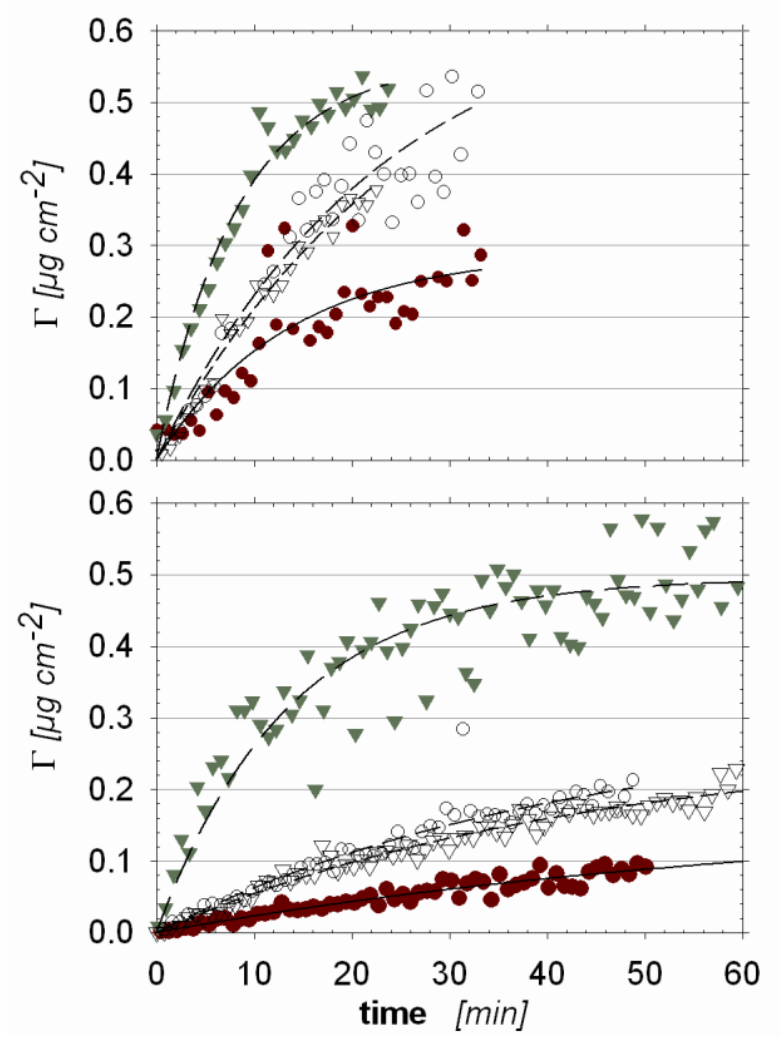

Figure 5 Adsorption kinetics of the oligomers on mica (o) in front of hydrophilic glass (•) and mica $(\nabla)$ in front of $\mathrm{C}_{10}$-glass $(\nabla)$ from $13.2 \mu \mathrm{g} / \mathrm{mL}$ solutions at $\mathrm{pH} 6.3$ (upper graph) and from $6.6 \mu \mathrm{g} / \mathrm{mL}$ solutions at $\mathrm{pH} 7.2$ (lower graph).

Whatever the $\mathrm{pH}$ value, adsorption onto mica was always intermediate between that on the two types of glasses. At pH 6.3 however, the differences between the surfaces tended to vanish, especially between mica and hydrophobized glass. Moreover, the two final behaviors 
for hydrophobic glass suggest the same limit of interfacial concentration probably close to the saturated surface. Given the size of the monomer $(7-8 \mathrm{~nm})$, a compact coverage of the surface would correspond to $0.26-0.20 \mu \mathrm{g} / \mathrm{cm}^{2}$ and according to the random sequential adsorption model ${ }^{37,38}$ to $0.16-0.12 \mu \mathrm{g} / \mathrm{cm}^{2}$. In addition, there is the question of the extent of spreading of the oligomers on the surface. For a spherical oligomer of $n$ monomers, the interfacial concentration varies with $n^{1 / 3}$. Whatever the exact value, it remains close to the order of magnitude of a monolayer of monomer or oligomers. To make visible the $\mathrm{pH}$ effect from experiments carried out at concentrations differing by a factor two, we gathered in Fig. 6 the Fig. 5 fit curves, for sake of clarity, with the time scale axes for the two series differing by the same factor.

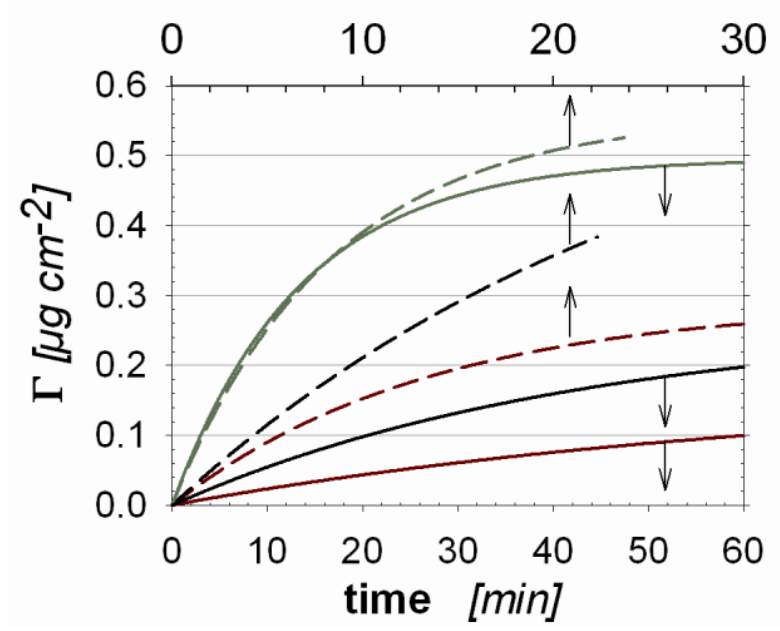

Figure 6 (Bottom time scale, full lines from bottom to top: hydrophilic glass, mica, hydrophobized glass) Interfacial concentration of oligomers as a function of time at $\mathrm{pH} 7.2$, $\mathrm{C}_{\mathrm{b}}=6.6 \mu \mathrm{g} / \mathrm{mL}$; (Top time scale, dashed lines: same order) $\mathrm{pH} 6.3, \mathrm{C}_{\mathrm{b}}=13.2 \mu \mathrm{g} / \mathrm{mL}$

We observed that the $\mathrm{pH}$ has no effect on the initial adsorption kinetics on hydrophobic glass while adsorption rate is a decreasing function of $\mathrm{pH}$ on mica and hydrophilic glass. The electrostatic interactions between protein and hydrophobic surface are not predominant in this range of $\mathrm{pH}$. With globally negatively charged protein above the isoelectric point, the more 
negative surfaces of mica and glass contribute as a repulsive component for adsorption. Another way to illustrate the $\mathrm{pH}$ effect is to compare the initial value of the kinetic constants $\left(1 / C_{\mathrm{b}}\right)(\mathrm{d} \Gamma / \mathrm{d} t)_{\mathrm{t}=0}($ Fig. 7$)$ : the constant in the presence of hydrophobized glass does not vary much between $\mathrm{pH} 6.3$ and $\mathrm{pH} 7.2$ while it is a decreasing function of $\mathrm{pH}$ for mica and hydrophilic glass. All these values are underestimated because of the smooth transition from buffer to solution, but the real ones should be positioned in the same order as hydrodynamic conditions were similar for all experiments.

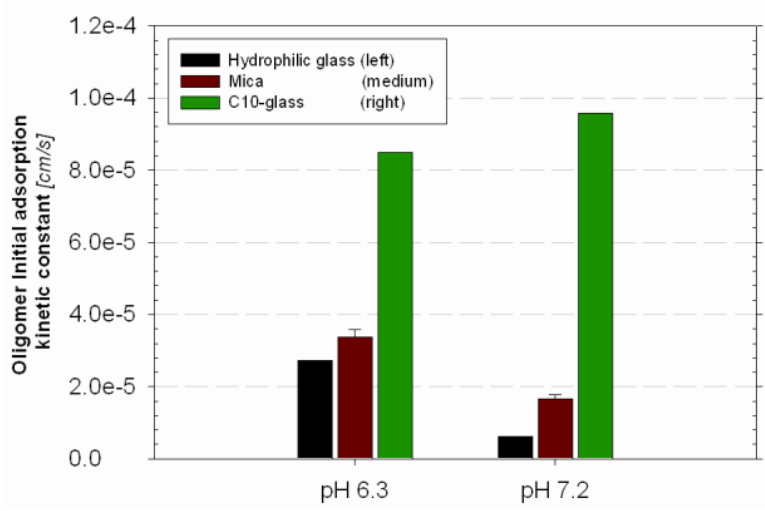

Figure 7 Initial kinetic constant for oligomers adsorption on hydrophilic glass, mica and C10glass at $\mathrm{pH} 6.3$ and 7.2 .

\section{Comparison between monomer and oligomers adsorption behavior}

From the previous results it is clear that the behaviors of monomer and oligomers are very different: much faster adsorption occurred for the oligomers than for the monomer over the three types of surface. Although most measurements were not continued until a plateau value was attained, it is very likely that the plateau values for monomer would not attain the corresponding values for oligomers, unless surface-induced conformational changes occur over larger time scales. In the period $30 \mathrm{~min}$ to $50 \mathrm{~min}$, there is a ratio of at least one order of magnitude between monomer and oligomers adsorption. In addition, the oligomers adsorption 
kinetics on hydrophobized glass was independent of $\mathrm{pH}$ (Fig. 6) in the studied range while the monomer adsorption kinetics was not (Fig. 4).

\section{Conclusion}

Scanning Confocal Fluorescence measurements have been used to investigate the adsorption behaviour of the $B t$ insecticidal protein, Cry1Aa, on macroscopic flat surfaces of mica and glass. This protein (pI 6.5) has a strong tendency to oligomerize and the adsorption properties of monomer and oligomers have been compared: they are very different.

In contrast with the often reported behavior of globular proteins near their isoelectric point, the adsorption of monomer CrylAa toxin was slow on both types of hydrophilic surfaces, mica and glass, and on the hydrophobic $\mathrm{C}_{10}$-treated glass. It should be pointed out however that the nature of the buffer, independently of $\mathrm{pH}$, may play a non negligible role. The influence of low molecular-weight organic acid ligands on toxin adsorption was previously studied ${ }^{3}$ and conclusion was drawn that the binding of the toxin on the minerals was looser in the presence of such ions. Inorganic salts can influence also the adsorption behavior $^{2}$.

Adsorption of the oligomeric state was greater and decreased in the order hydrophobized glass $>$ mica $>$ hydrophilic glass. The high adsorption of oligomers on hydrophobic surface may result from neutralizing electric patches in the association that exposes hydrophobic residues in patches facing the hydrophobic surface. On such kind of surfaces we observed a strong dependence on $\mathrm{pH}$ for monomer contrary to oligomers. The kinetic curve shapes for the monomer on hydrophilic glass differ notably from those for the oligomers. They may be related to conformational changes induced at the interfaces, while similar modifications could already have occurred in the oligomerization process. Whatever the type of mechanism, the present study suggests that $B t$ toxin is more easily adsorbed in the oligomer state over various types of surface. 
This result, obtained with fluorescently-tagged protein, suggests quicker and larger retention of the toxin in any soil if aggregation had occurred.

About the technique of fluorescence applied here to adsorption studies, it represents a first step towards determining the profile of concentration in solution near the interface concomitantly to the interfacial concentration as a function of time. Deconvolution of surface and solution signals is presently under investigation. It should bring a direct new way towards determination of kinetic parameters which are dependent on surface availability and adsorption history ${ }^{39,40}$. Still the present semi-quantitative study can become more quantitative with determination of the ratio $V / A$ and improving the sharpness of transition between the flows of buffer and solution.

Acknowledgments. The authors are grateful for the financial support of Agence Nationale de la Recherche under contract ANR-05-POGM-002-03. The authors thank R. Frutos for valuable discussion, M. Royer for providing the $B t$ strain and the cultivation-extraction protocol, F.X. Sauvage for protein analysis, INRA Narbonne for providing the fermentor, and INRA proteomic platform for the mass spectroscopy analyses.

\section{References}

1. Fu, Q. L.; Deng, Y. L.; Li, H. S.; Liu, J.; Hu, H. Q.; Chen, S. W.; Sa, T. M., Applied Surface Science 2009, 255, 4551-4557.

2. Fu, Q. L.; Wang, W. Q.; Hu, H. Q.; Chen, S. W., European Journal of Soil Science 2008, 59, 216-221.

3. Fu, Q. L.; Dong, Y. J.; Hu, H. Q.; Huang, Q. Y., Applied Clay Science 2007, 37, 201206.

4. Helassa, N.; Quiquampoix, H.; Noinville, S.; Szponarski, W.; Staunton, S., Soil Biology and Biochemistry 2009, 41, 498-504.

5. Zhou, X. Y.; Huang, Q. Y.; Cai, P.; Yu, Z. N., Pedosphere 2007, 17, 513-521.

6. Norde, W.; MacRitchie, F.; Nowicka, G.; Lyklema, J., Journal of Colloid and Interface Science 1986, 112, 447-456.

7. Norde, W.; Anusiem, A. C. I., Colloids Surf. 1992, 66, 73-80.

8. Le, M. T.; Dejardin, P., Langmuir 1998, 14, 3356-3364.

9. Etheve, J.; Dejardin, P.; Boissiere, M., Colloids and Surfaces B: Biointerfaces 2003, 28, 285-293.

10. Tapp, H.; Stotzky, G., Soil Biology \& Biochemistry 1998, 30, 471-476. 
11. Saxena, D.; Flores, S.; Stotzky, G., Soil Biology \& Biochemistry 2002, 34, 133-137.

12. Tapp, H.; Stotzky, G., Applied and Environmental Microbiology 1995, 61, 1786-1790.

13. Guereca, L.; Bravo, A., Biochimica Et Biophysica Acta-Protein Structure and Molecular Enzymology 1999, 1429, 342-350.

14. Masson, L.; Mazza, A.; Sangadala, S.; Adang, M. J.; Brousseau, R., Biochimica Et Biophysica Acta-Protein Structure and Molecular Enzymology 2002, 1594, 266-275.

15. Walters, F. S.; Kulesza, C. A.; Phillips, A. T.; English, L. H., Insect Biochemistry and Molecular Biology 1994, 24, 963-968.

16. Vie, V.; Van Mau, N.; Pomarede, P.; Dance, C.; Schwartz, J. L.; Laprade, R.; Frutos, R.; Rang, C.; Masson, L.; Heitz, F.; Le Grimellec, C., Journal of Membrane Biology 2001, 180, 195-203.

17. Vasina, E. N.; Dejardin, P., Biomacromolecules 2003, 4, 304-313.

18. Vasina, E. N.; Dejardin, P., Langmuir 2004, 20, 8699-8706.

19. Vasina, E. N.; Dejardin, P.; Rezaei, H.; Grosclaude, J.; Quiquampoix, H., Biomacromolecules 2005, 6, 3425-3432.

20. Borisova, S.; Grochulski, P.; van Faassen, H.; Pusztai-Carey, M.; Masson, L.; Cygler, M., Journal of Molecular Biology 1994, 243, 530-532.

21. Grochulski, P.; Masson, L.; Borisova, S.; Pusztaicarey, M.; Schwartz, J. L.; Brousseau, R.; Cygler, M., Journal of Molecular Biology 1995, 254, 447-464.

22. Chevallier, T.; Muchaonyerwa, P.; Chenu, C., Soil Biology \& Biochemistry 2003, 35, 1211-1218.

23. Perrot, H.; Jaffrezic-Renault, N.; Clechet, P., Journal of the Electrochemical Society 1990, 137, 598-602.

24. Zhuravlev, L. T., Langmuir 1987, 3, 316-318.

25. Legrand, A. P., The surface properties of silicas. In Wiley: Chichester, 1998; p 367.

26. Balme, S.; Janot, J.-M.; Dejardin, P.; Vasina, E. N.; Seta, P., Journal of Membrane Science 2006, 284, 198-204.

27. Lévêque, M., Les lois de transmission de la chaleur par convection. Faculté des Sciences: Paris, 1928.

28. Levich, V. G., Physical hydrodynamics. Prentice-hall, Inc., Englewood Cliffs, N.J.: 1962.

29. Dejardin, P.; Le, M. T.; Wittmer, J.; Johner, A., Langmuir 1994, 10, 3898-3901.

30. Dejardin, P.; Vasina, E. N., Colloids and Surfaces B: Biointerfaces 2004, 33, 121-127.

31. Déjardin, P.; Vasina, E. N., Initial adsorption kinetics in a rectangular thin channel and coverage-dependent structural transition observed by streaming potential. In Proteins at SolidLiquid Interfaces, Déjardin, P., Ed. Springer: Berlin, 2006; pp 51-73.

32. Yan, F.; Dejardin, P.; Mulvihill, J. N.; Cazenave, J. P.; Crost, T.; Thomas, M.; Pusineri, C., Journal of Biomaterials Science-Polymer Edition 1992, 3, 389-402.

33. Boumaza, F.; Dejardin, P.; Yan, F.; Bauduin, F.; Holl, Y., Biophysical Chemistry 1992, 42, 87-92.

34. Robeson, J. L.; Tilton, R. D., Langmuir 1996, 12, 6104-6113.

35. Daly, S. M.; Przybycien, T. M.; Tilton, R. D., Langmuir 2003, 19, 3848-3857.

36. Daly, S. M.; Przybycien, T. M.; Tilton, R. D., Colloids and Surfaces B-Biointerfaces 2007, 57, 81-88.

37. Schaaf, P.; Talbot, J., Journal of Chemical Physics 1989, 91, 4401-4409.

38. Schaaf, P.; Voegel, J. C.; Senger, B., Journal of Physical Chemistry B 2000, 104, 2204-2214.

39. Calonder, C.; Tie, Y.; Van Tassel, P. R., Proceedings of the National Academy of Sciences of the United States of America 2001, 98, 10664-10669. 
40. Tie, Y.; Calonder, C.; Van Tassel, P. R., Journal of Colloid and Interface Science 2003, 268, 1-11.

\section{TOC Graphic}

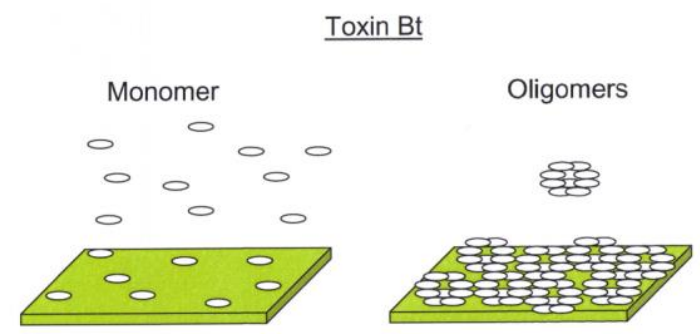

